Article

\title{
The Impact of Climate Change on Water Resource Availability in a Trans-Boundary Basin in West Africa: The Case of Sassandra
}

\author{
Naga Coulibaly ${ }^{1, *}$, Talnan Jean Honoré Coulibaly ${ }^{1}$, Ziyanda Mpakama $^{2}$ and Issiaka Savané ${ }^{1}$ \\ 1 Laboratoire de Géosciences et Environnement, UFR des Sciences et gestion de l'Environnement, \\ Université Nangui Abrogoua, Abidjan, Cote d'Ivoire; ctalnan@yahoo.fr (T.J.H.C.); \\ savanei@hotmail.com (I.S.) \\ 2 Programme Manager Africa Regional Centre, Stockholm International Water Institute (SIWI), Pretoria 0181, \\ South Africa; ziyanda.mpakama@siwi.org \\ * Correspondence: coulibalynaga_sge@una.edu.ci; Tel.: +225-05-83-75-99
}

Received: 6 November 2017; Accepted: 25 January 2018; Published: 29 January 2018

\begin{abstract}
In the context of climate change in West Africa characterized by a reduction of precipitation, this study was conducted to evaluate the impact of climate change on water resources from now to the end of the 21st century in the transboundary watershed of the Sassandra River shared by Guinea and Côte d'Ivoire. Historical and future climate data of Representative Concentration Pathways (RCPs) 4.5 and 8.5 were projected with the Abdus Salam International Centre for Theoretical Physics (ICTP) Regional Climate Model (RegCM4). The hydrological modeling of the river basin was carried out with the conceptual hydrological model, GR2M, a monthly time steps model that allows for the assessment of the discharge of the Sassandra River for each climate scenario according to the time periods 2021-2040 (Horizon 2030), 2041-2060 (Horizon 2050), 2061-2080 (Horizon 2050), and 2081-2100 (Horizon 2090). The results show a reduction in annual discharge when compared to the baseline (1961-1980). For RCP 4.5, the observed values go from $-1.2 \%$ in 2030 to $-2.3 \%$ in 2070 and rise to $-2.1 \%$ in 2090. Concerning RCP 8.5, we saw a variation from -4.2 to $-7.9 \%$ in Horizons 2030 and 2090, respectively. With the general decrease in rainfall in West Africa, it is appropriate to assess the impact on water resources of the largest rivers (Niger, Gambia, and Senegal) that irrigate the Sahelo-Saharian zone.
\end{abstract}

Keywords: climate change; GR2M; hydrologic modeling; transboundary river; West Africa

\section{Introduction}

West Africa is relatively well endowed with water resources that are renewed each year through a normal hydrological cycle [1]. Thus, the problem with water is not so much the total quantity of water availability in the region, but its unequal distribution in space and time. In this context, Guinea has the particularity of being the main water provider for many countries in the region, hence Guinea's being known as the "water tower" of West Africa. Indeed, Guinea possesses 14 transboundary rivers, and the springs of this river system are based in this country [2]. According to the study of Sidibé and Oulaye [3], $130 \mathrm{~km}^{3}$ of water leaves the territory of Guinea annually to supply the biggest rivers of West Africa (Niger, Senegal, and Gambia), flowing to the Sahelian countries (Mali, Mauritania, Niger) and to many rivers in Côte d'Ivoire, Guinea-Bissau, Sierra Leone, and Liberia (namely the Makona, Loffa, Cavaly, Bafing, Bagbé, and Sassandra Rivers).

Climate change caused by the increase in greenhouse gases in the atmosphere has significantly influenced the water balance by causing changes in evapotranspiration rates, temperature, and rainfall [4]. In West Africa, these changes have had a negative impact on the water resource availability, as water resources are dwindling in the region due to the overall decline of rainfall [5-14]. 
Several studies have been carried out in the transboundary river basin of Sassandra concerning the assessment and management of water resources [15-22], particularly, Ardoin et al. [19], Rescan, [20] and Yao [22], who used the Génie Rural à 2 paramètres Mensuel (GR2M) hydrological model. The works of Ardoin et al. [19] and Rescan [20] showed that the Sassandra River runoff and water availability would increase from 10 to $13 \%$ during the first half of the 21st century (Horizon 2050) before decreasing at the Horizon 2080 when compared to the reference period 1971-1995. The latter in their studies modeled climate from the HadCM3 global climate model of spatial resolution, $2.5^{\circ} \times 3.75^{\circ}$ with the A2 greenhouse gas emission scenario. Recently, Yao [22] worked on the hydrologic modeling of a tributary of the Sassandra River (the Lobo). This study was carried out using the regional climate model RegCM3 of spatial resolution of $0.44^{\circ} \times 0.44^{\circ}$ under the A1B emission scenario. Yao [22] improved a deficiency by reducing the scale of climate modeling to better appreciate local specificities.

This study, which concerns almost all of the watershed of Sassandra, used climate data generated from the RegCM version 4 model under Representative Concentration Pathways (RCPs) 4.5 and 8.5 (spatial resolution: $0.25^{\circ} \times 0.25^{\circ}$ ) first to evaluate climate change in West Africa and its impact on the natural discharge of Sassandra River at Soubré and second to estimate the headwater inflow from Guinea, the water tower of West Africa, to Côte d'Ivoire.

\section{Materials and Methods}

\subsection{Study Area}

The Sassandra River is a transboundary river located in West Africa that has its spring in the Forest Guinea (Guinea) and Denguélé (Côte d'Ivoire) regions. It crosses the western part of Côte $\mathrm{d}$ 'Ivoire and flows into the Gulf of Guinea at the city of Sassandra. It extends from $5.5^{\circ}$ to $10.5^{\circ}$ of North latitude with a total length of $650 \mathrm{~km}$ (Figure 1). The area of the basin is $62,700 \mathrm{~km}^{2}$ of which $13 \%$ belong to Guinea. Elongated with Kc equal to 1.39, the Sassandra River Basin has no pronounced topography, except in the Guinean part where the peaks are around $1300 \mathrm{~m}$ and in the Man region where Mount Tonkpi peaks at $1190 \mathrm{~m}$. The mean of the basin altitude is $385 \mathrm{~m}$.

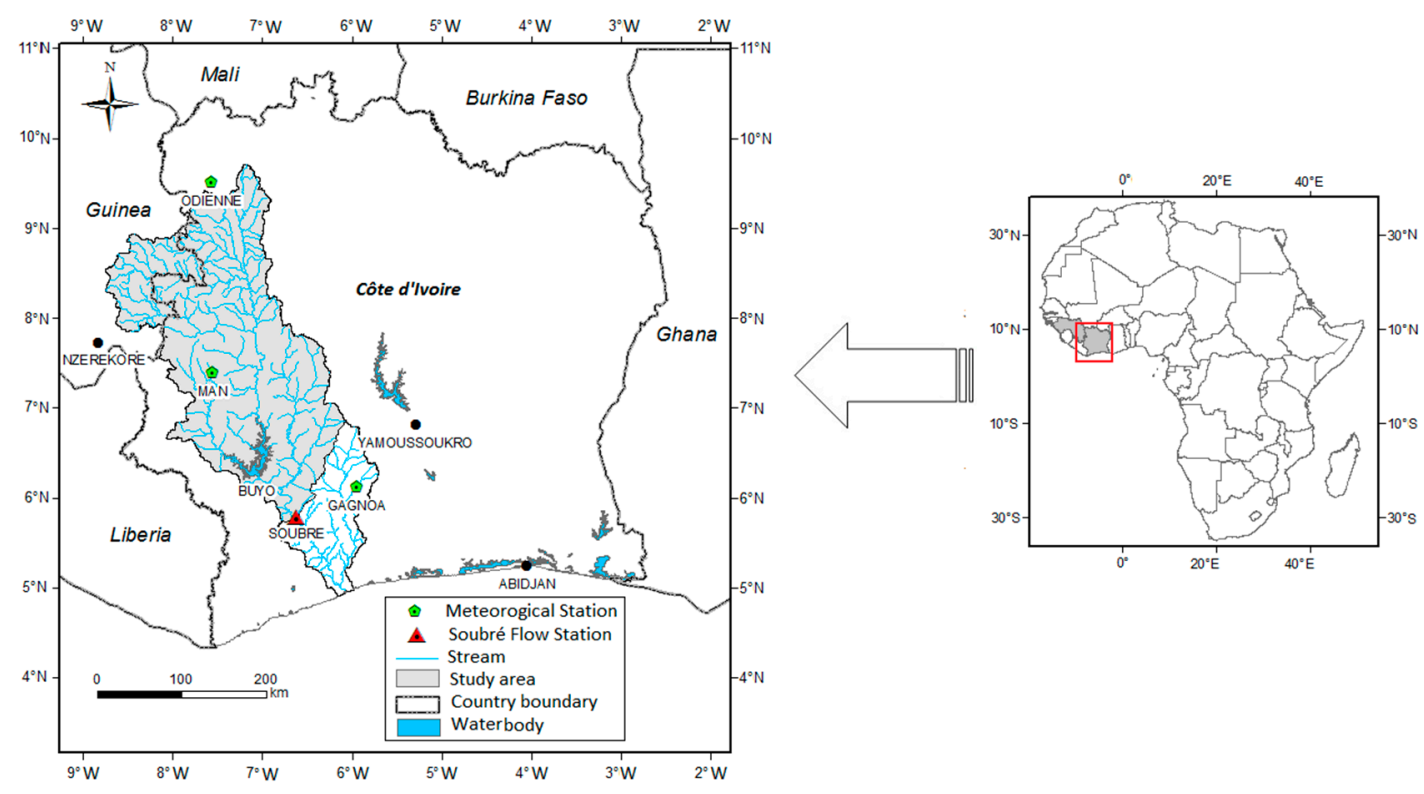

Figure 1. Sassandra River Basin at Soubré.

The Sassandra Basin spreads over three different climatic regions where hydrological regimes are quite similar to precipitation regimes [23]. In the south, a humid tropical climate is observed and corresponds to the region of Soubré-Gagnoa. It is characterized by two rainy seasons from March to 
June and from September to October, and two dry seasons that go from November to February and from July to August. The northern part of the river basin is characterized by a transitional tropical climate or a Sudanese climate (station of Odienné) where the most abundant annual precipitation occurs mostly during the months of July, August, and September. From November to March-April, there is drought. The mountain climate is located in the center-west of the basin in the mountains of Man. This climate is characterized by a short dry season (November to February) and a rainy season that extends from March to October with the precipitation peak in September. The Forest Guinea region is characterized by a long rainy season of 9-10 months. The annual rainfall varies between 1700 and $2500 \mathrm{~mm}$. Figure 2 and Table 1 summarize the characteristics of the basin's climate.

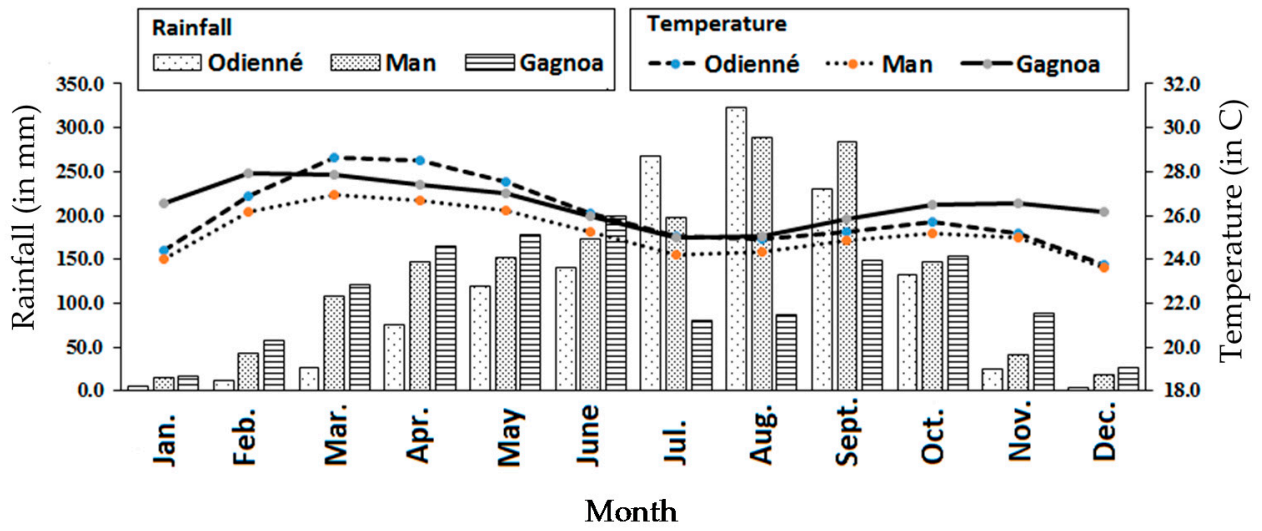

Figure 2. Rainfall and temperature monthly averages over 30 years (1961-1990).

Table 1. Rainfall and temperature annual averages over 30 years (1961-1990).

\begin{tabular}{cccccc}
\hline & $\begin{array}{c}\text { Longitude } \\
\text { (Decimal Degree) }\end{array}$ & $\begin{array}{c}\text { Latitude } \\
\text { (Decimal Degree) }\end{array}$ & $\begin{array}{c}\text { Temperature } \\
\text { (in }{ }^{\circ} \text { C) }\end{array}$ & $\begin{array}{c}\text { Rainfall } \\
\text { (in mm) }\end{array}$ & $\begin{array}{c}\text { PET } \\
\text { (in mm) }\end{array}$ \\
\hline Odienné & -7.5660 & 9.5000 & 26.0 & 1365.9 & 1559.9 \\
Man & -7.5167 & 7.4000 & 25.2 & 1617.8 & 1411.0 \\
Gagnoa & -5.9500 & 6.1333 & 26.5 & 1322.7 & 1632.4 \\
Average & - & - & 25.9 & 1435.5 & 1534.4 \\
\hline
\end{tabular}

The Sassandra possess two hydroelectric dams: Buyo, built in 1980 (capacity, 165 MW), and Soubré (capacity, $270 \mathrm{MW}$ ), whose construction was completed in 2017. The annual mean discharge at the station of Soubré was about $500 \mathrm{~m}^{3} / \mathrm{s}$ before 1980 (1954-1980) and $331 \mathrm{~m}^{3} / \mathrm{s}$ afterward (1981-2005). Regarding vegetation, the natural ecosystems in the basin are shared between the wooded savannah in the northeast and the humid dense forest in the center and south of the basin [24]. Since the 1960s, in the Ivorian part of the basin, human activities have been conducted such as timber extraction for export and the mobilization of vast territories for cash crops and industries (cotton, cocoa, coffee, rubber, and palm oil), then to the shifting cultivation on slash-and-burn [25]. Today, with the economic recovery and its opening to the outside world, the annual deforestation rate in Guinea is estimated at $0.5 \%$, i.e., about 35,000 ha of forests lost every year due to agriculture, mining exploitation (bauxite and other minerals), fuelwood, and service harvesting [26]. The geology consists essentially of the Precambrian basement. The soils are ferralitic type and not very permeable, but have a significant retention capacity [27]. 


\subsection{Available Data}

\subsubsection{Historical Data}

The monthly observed climatic data (precipitation and temperature) from 1956 to 1980 used in this study was provided by the Société d'Exploitation et de Développement Aéroportuaire, Aéronautique et Météorologique (SODEXAM).

The river discharge data at the station of Soubré were from the database of the Office National d'Eau potable (ONEP). These were the monthly flows from 1956 to 1980; after 1980, the Buyo dam located upstream of the Soubré station no longer allowed a natural flow. These flows were converted into depth of runoff flowed for the calibration and validation of the hydrological model.

The soil characteristics or the water holding capacity (WHC) of the soil reservoir of the hydrological model GR2M corresponded to the soil water capacity. This information was estimated using the FAO Soil Map (FAO-UNESCO 1974-1981). This consisted in calculating the average of the capacities of all soil types in the watershed through weighting with their respective superficies.

\subsubsection{Future Climate Simulated Data}

The future climate data were provided by the United Nations University Institute for Natural Resources in Africa (UNU-INRA) in Accra (Ghana). These data include daily temperature, precipitation, and potential evapotranspiration (PET) of the Economic Community of West African States (ECOWAS) zone projected by Sylla [28] up to 2100. The methodology used to simulate these climate data was the Abdus Salam International Centre for Theoretical Physics (ICTP) Regional Climate Model version 4 (RegCM4; [29]). Indeed, RegCM4 has been used at a resolution of $0.25^{\circ} \times 0.25^{\circ}(25 \mathrm{~km} \times 25 \mathrm{~km})$ to dynamically downscale a set of CMIP5 ESMs over West Africa for the two Intergovernmental Panel on Climate Change (IPCC) core RCPs (RCP 4.5 and RCP 8.5). The driving data were derived from the CMIP5 Global Climate Models (GCMs).

The basic strategy has been to use the GCMs to simulate the response of the global circulation to large-scale forcings and the RCM to (a) account for sub-GCM grid scale forcings (e.g., complex topographical features and land cover heterogeneities) in a physically based way and (b) enhance the simulation of atmospheric circulations and climatic variables at fine spatial scales. This technique therefore constitutes the most appropriate tool to generate regional climate change data for West Africa and has been used extensively over the region (e.g., [30-34]). For more details about the CMIP5 models, see Taylor et al. [35].

\subsection{Climate Change Analysis}

We compared the annual simulated climate data up to 2100 according to RCPs 4.5 and 8.5 with observation values in a baseline period (1961-1980). Thus, the variations of mean precipitation, temperature, or basin discharge at different time periods were calculated in relation to the baseline period (1961-1980). The four time periods were 2021-2040 (Horizon 2030), 2041-2060 (Horizon 2050), 2061-2080 (Horizon 2070), and 2081-2100 (Horizon 2090). The variations are expressed as a percentage and are calculated according to the following formula:

$$
\Delta_{i}^{\text {hori }}=100 \times \frac{\left(\overline{X_{i}^{\text {hor }}}-\overline{X^{\text {ref }}}\right)}{X^{\text {ref }}}
$$

where $\overline{\Delta_{\mathrm{i}}^{\text {hor }}}$ is the annual mean value calculated over the specified time period, $\overline{\mathrm{X}^{\text {ref }}}$ is the annual mean value calculated over the reference period, and i is the time step (Horizons 2030, 2050, 2070, 2090).

This rate of change represents the relative increase or decrease in annual precipitation, temperature, or basin discharge for the future. 


\subsection{Bias Correction or Delta Approach}

Climate models often have biases in climate simulation. This was the case for the projected climate data used in this study. Indeed, rainfall is significantly underestimated. Temperatures are also underestimated, but to a lesser extent. Thus, before using these data for the hydrological modeling, we corrected these errors using the delta approach. This approach was applied to the most relevant climate variables in hydrology, notably rainfall, temperature, and $\mathrm{ET}_{0}$ [36]. It defines certain correction factors by comparing the statistical properties of simulated variables during the reference period to those of the historical observations. These factors are then applied to the climate simulations to correct the biases. The method corrects for two types of disturbances:

- "additive" disturbances for temperatures:

$$
T_{s c e n, j, h}=T_{o b s, j}+\left(T_{s c e n, m, h}-T_{r e f, m}\right)
$$

where $T_{s c e n, j, h}$ is the daily temperature of the considered time period, $T_{o b s, j}$ is the daily observed temperature, $T_{\text {scen, } m, h}$ is the monthly inter-annual mean temperature of the time period considered, $T_{r e f, m}$ is the monthly inter-annual mean temperature of the reference period, and $T_{s c e n, m, h}-T_{r e f, m}$ is delta $T$;

- "multiplicative" disturbances for the precipitations:

$$
P_{\text {scen }, j, h}=P_{o b s, j} \times\left(P_{s c e n, m, h} / P_{r e f, m}\right)
$$

where $P_{s c e n, j, h}$ is the daily precipitation of the considered time period, $P_{o b s, j}$ is the daily precipitation observed, $P_{s c e n, m, h}$ is the monthly inter-annual mean precipitation of the time period considered, $P_{r e f, m}$ is the monthly inter-annual mean precipitation of the reference period, and $P_{s c e n, m, h} / P_{\text {ref, } m}$ is the delta $P / P$ or $\Delta \mathrm{P}$ or ratio.

\subsection{The Hydrological Model: GR2M}

For the hydrological modeling of the Sassandra watershed, the Génie Rural à 2 paramètres Mensuel (or GR2M) model was used in this study. GR2M is a conceptual rainfall-flow model with two reservoirs. The reservoir $S$ has a capacity maximum $X_{1}$ that carries out the simulation of discharge on a monthly basis from rainfall data and mean monthly evapotranspiration over a basin. The concept pattern of the model is shown in Figure 3 and described has follow [37]. In the GR2M model, the production function relies on a soil moisture store (S). Given a precipitation $\mathrm{P}$, the level $\mathrm{S}$ in the store becomes $S_{1}$. The parameter $X_{1}$, the maximum capacity of the store, is positive and is given in $\mathrm{mm}$. The excess precipitation is given by $\mathrm{P}_{1}$. Given the potential evapotranspiration $\mathrm{E}$, the level $\mathrm{S}_{1}$ becomes $S_{2}$. The production store $\left(X_{1}\right)$ then empties with a percolation $P_{2}$ and its level, ready for the computations of the following month, given by $\mathrm{S}$. The total precipitation that reaches the routing store is given by $P_{3}$. The level $R$ in the routing store then becomes $R_{1}$. The parameter $X_{2}$ is positive and has no dimension. The level in the store becomes $R_{2}$. The store, with a fixed capacity equal to $60 \mathrm{~mm}$, empties following a quadratic function. The streamflow is given by $\mathrm{Q}$. The model has two parameters to optimize during its calibration:

- $\quad \mathrm{X}_{1}$ : the capacity of the production store $(\mathrm{mm})$;

- $\quad X_{2}$ : the exchange coefficient (no dimension).

The use of the GR2M model has yielded good results on several basins in West Africa [13,19,20,22,38].

For calibration and validation of the model, testing of the different sub-divisions of the discharge series was conducted using the method described by Mouelhi et al. [37]. The best periods were 1961-1967 and 1971-1977 for calibration and validation, respectively. In order to use the optimization 
criteria, we chose the objective form proposed by Perrin [39], which is a modification of the explanation coefficient for Nash and Sutcliffe [40], called "NASH":

$$
N A S H=\left[1-\frac{\sum_{i}\left(Q_{o}^{i}-Q_{c}^{i}\right)^{2}}{\sum_{i}\left(Q_{o}^{i}-Q_{m}\right)^{2}}\right]
$$

where $Q_{o}^{i}$ and $Q_{c}^{i}$ indicate the observed and calculated flows, respectively, and the $Q_{m}$ is the observed mean flow over the whole period of observation without any missing data. The model is considered to be performing well when the estimated flows approach the observed flow, that is, when the NASH criterion value is close to 1 . We can affirm that values less than 0.6 indicate an important difference between the observed and simulated discharge by the model.

The simulation of future discharge was carried out for the period from 2021 to 2100 . The input data, precipitation, and potential evapotranspiration (PET) were simulated according to RCPs 4.5 and 8.5. Ultimately, nine simulations were carried out: one simulation for the historical period of 1961-1980, and eight simulations for RCPs 4.5 and 8.5 for Horizons 2040, 2060, 2080, and 2100. To make simulation possible, the parameters $\left(\mathrm{X}_{1}\right.$ and $\left.\mathrm{X}_{2}\right)$ used for calibration and validation over the periods already observed were kept constant.

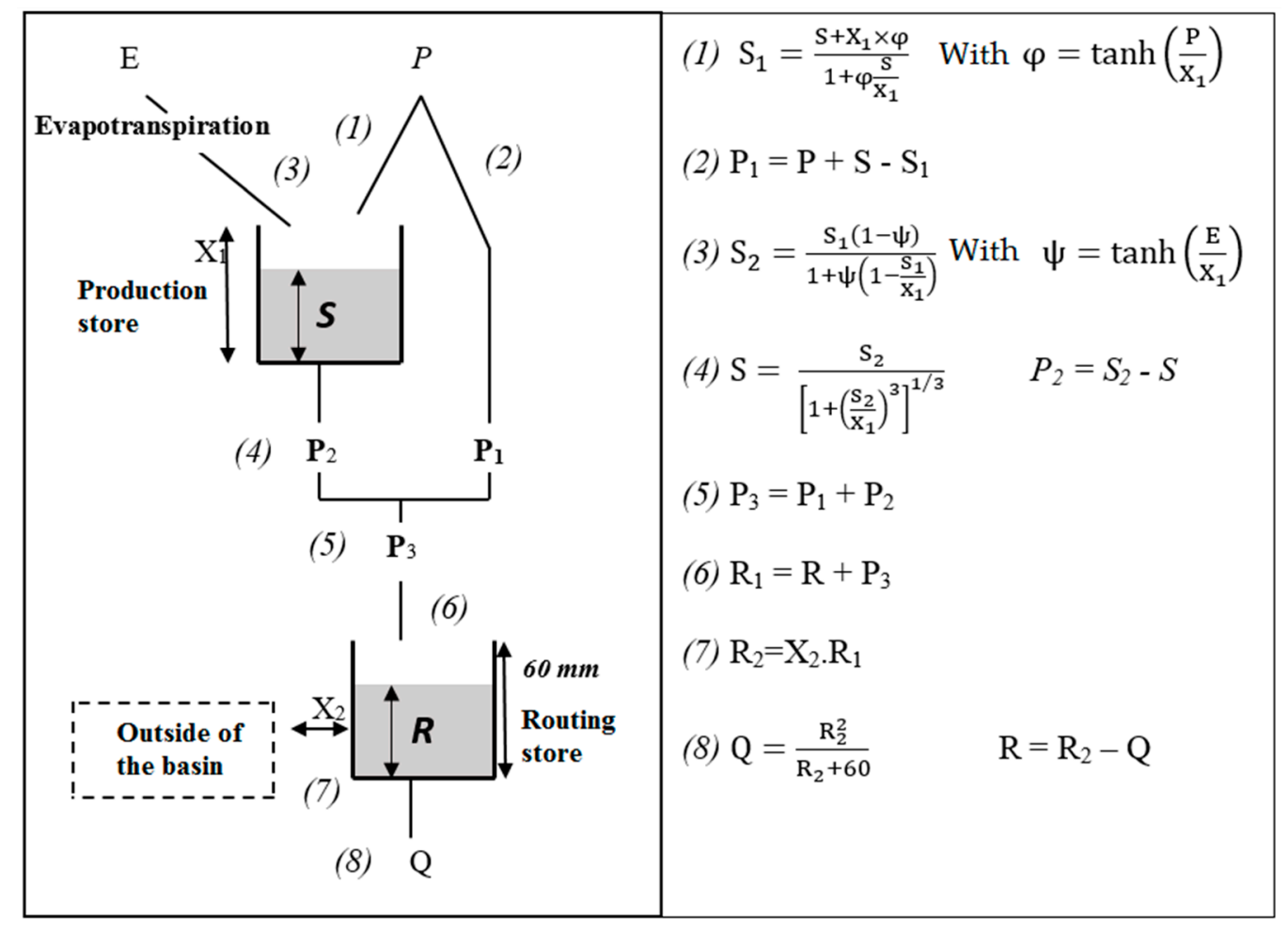

Figure 3. Scheme of the conceptual model GR2M (Source, [37]).

\subsection{Headwater Inflows from Guinea Assessment}

To evaluate the quantity of water coming from Guinea, which supplies the Sassandra River, we were confronted by a lack of data for modeling with GR2M. We estimated the variation of this quantity based on the results of Roudier et al. [41]. Indeed, according to the study, the change in runoff is a function of the variation in precipitation in the Sassandra Basin according to Equation (5). Thus, the projected flows were calculated from Equation (5) and the projected precipitation data on the Guinean part of the basin according to RCPs 4.5 and 8.5.

$$
\text { Runoff change }=2.0 \times \text { rainfall change }+7.7
$$


This equation was established with a Pearson coefficient of correlation equal to 0.68 for the Sassandra River Basin.

\section{Results and Discussions}

\subsection{Climate Change Analysis}

\subsubsection{Temperatures}

Figure 4 presents the inter-annual monthly mean temperatures of the Sassandra catchment obtained from projected climate data according to RCPs 4.5 and 8.5. It shows a continuous increase in projected temperatures up to 2090 when compared to the value observed during the baseline period (1961-1980), i.e., $25.9{ }^{\circ} \mathrm{C}$, regardless of the climate scenario. This increase in temperature was more marked in RCP 8.5, which is the most pessimistic scenario [42]. Indeed, the highest temperatures were observed during RCP 8.5. Thus, by Horizon 2090, the mean temperature in the watershed will be $32.9^{\circ} \mathrm{C}$ during the month of March (hottest month) and $29.6^{\circ} \mathrm{C}$ in July (coolest month). For RCP 4.5, the temperatures will be $30.2{ }^{\circ} \mathrm{C}$ and $27.2{ }^{\circ} \mathrm{C}$ for the months of March and July, respectively. According to the conclusions of Sylla [28] for the West African region, our analysis for the Sassandra Basin showed significant variations in extreme values (low and high temperatures). Thus, for the extreme months (March and July), we observed average variations around $+5.1{ }^{\circ} \mathrm{C}$ and the other months showed average increases of $+4.8^{\circ} \mathrm{C}$ in Horizon 2090 .

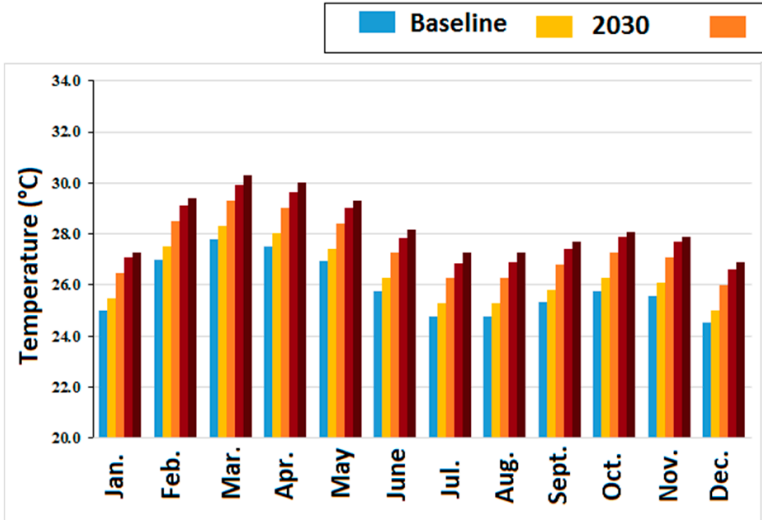

(a)

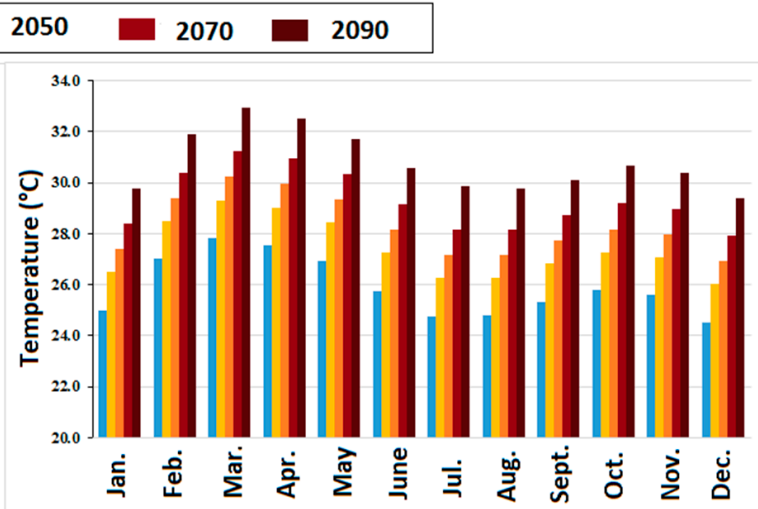

(b)

Figure 4. Variation in the monthly interannual mean temperatures for Horizons 2030, 2050, 2070, and 2090 in the Sassandra River Basin: (a) RCP 4.5; (b) RCP 8.5.

These results confirmed the analysis of Sylla [43] and the last IPCC report concerning the projected temperatures in West Africa. Indeed, West Africa is expected to be strongly impacted by temperature increase. The latest IPCC report showed a warming range of $3-6^{\circ} \mathrm{C}$ above the late 20 th century baseline.

The analysis of the projected annual mean temperatures under scenarios RCPs 4.5 and 8.5 showed a rising temperature trend when compared to the baseline (1961-1980) in the Sassandra River Basin (Table 2). The maximal increase, $17.4 \%\left(+5^{\circ} \mathrm{C}\right)$ was observed at Horizon 2090 and for scenario RCP 8.5. For the same scenario, temperatures will increase by $5.9 \%, 9.3 \%$, and $13.3 \%$ for Horizons 2030 , 2050, and 2070, respectively. For RCP 4.5, we will reach an increase of $2.1^{\circ} \mathrm{C}$ by 2090 (i.e., $+9.1 \%$ ). The variations observed in this study were close to the results of Ardoin et al. [19] and Soro et al. [44]. Soro et al. [44] obtained a temperature increasing 20\% for Horizon 2075 (2066-2085) under RCP 8.5 in the Bandama River Basin (Côte d'Ivoire) and Ardoin et al. [19] obtained the same augmentation using for the future climate projections, the HadCM3 model, and the A2 greenhouse gas emission scenario in West Africa. 
Table 2. Projected changes of temperature and rainfall for the 21st century in the Sassandra River Basin under RCPs 4.5 and 8.5 .

\begin{tabular}{|c|c|c|c|c|c|c|c|c|c|c|}
\hline & & Baseline & \multicolumn{2}{|c|}{2030} & \multicolumn{2}{|c|}{2050} & \multicolumn{2}{|c|}{2070} & \multicolumn{2}{|c|}{2090} \\
\hline Temperature & RCP 4.5 & $25.9^{\circ} \mathrm{C}$ & $26.4^{\circ} \mathrm{C}$ & $+2 \%$ & $27.4^{\circ} \mathrm{C}$ & $+6 \%$ & $28^{\circ} \mathrm{C}$ & $+8 \%$ & $28.3^{\circ} \mathrm{C}$ & $+9 \%$ \\
\hline \multirow{2}{*}{ Rainfall } & RCP 4.5 & \multirow{2}{*}{$1435.5 \mathrm{~mm}$} & $1330.1 \mathrm{~mm}$ & $-7 \%$ & $1310.2 \mathrm{~mm}$ & $-9 \%$ & $1295.4 \mathrm{~mm}$ & $-10 \%$ & $1296.6 \mathrm{~mm}$ & $-10 \%$ \\
\hline & RCP 8.5 & & $1224.7 \mathrm{~mm}$ & $-15 \%$ & $1185 \mathrm{~mm}$ & $-17 \%$ & $1155.3 \mathrm{~mm}$ & $-20 \%$ & $1088.8 \mathrm{~mm}$ & $-24 \%$ \\
\hline
\end{tabular}

\subsubsection{Rainfall}

The monthly inter-annual rainfall observed in the baseline period and projected under RCPs 4.5 and 8.5 for Horizons 2030, 2050, 2070, and 2090 is presented in Figure 5. For both climate scenarios, there was an overall decrease in average monthly precipitation when compared to the values observed during the reference period $(1435.5 \mathrm{~mm})$. Additionally, the diagrams of monthly rainfall of the Sassandra watershed had different courses according to RCPs 4.5 and 8.5. Indeed, at the baseline, the monthly inter-annual average of precipitation of the watershed was similar to the mountain climate (Figure 2) located around the locality of Man and was characterized by a long rainy season. These characteristics kept constant during RCP 4.5 (Figure 5a). Furthermore, this scenario showed a decrease in rainfall until the 2070s and a slight recovery in 2090. For RCP 8.5, the seasonal variation evolved towards a Sudanese climate type (Figure 2) materialized by a shortening of the rainy season and an elongation of the dry season (Figure $5 b$ ).

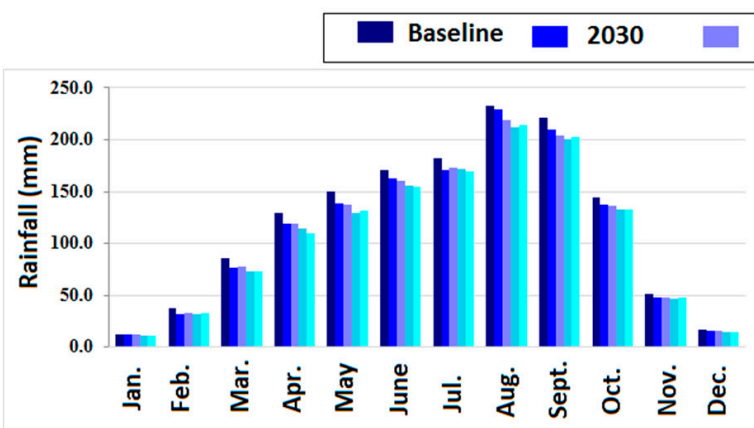

(a)

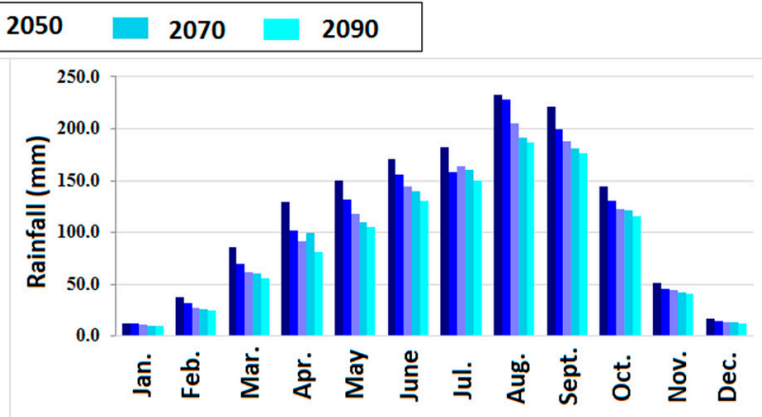

(b)

Figure 5. Monthly inter-annual mean rainfall for Horizons 2030, 2050, 2070, and 2090 in the Sassandra River Basin: (a) RCP 4.5; (b) RCP 8.5.

For annual mean rainfall, Table 2 shows a decrease for the two scenarios in the basin with a more pronounced reduction for RCP 8.5. RCP 8.5 will therefore create the worst situation when compared to the baseline (1961-1980) with a reduction of $24 \%$ at Horizon 2090. The annual mean rainfall for the baseline period was $1435.5 \mathrm{~mm}$. We will have $1330.1 \mathrm{~mm}, 1310.2 \mathrm{~mm}, 1295.5 \mathrm{~mm}$, and $1296.6 \mathrm{~mm}$ for RCP 4.5 and $1224.7 \mathrm{~mm}, 1185 \mathrm{~mm}, 1155.3 \mathrm{~mm}$, and $1088.8 \mathrm{~mm}$ for RCP 8.5, respectively, for the Horizons 2030, 2050, 2070, and 2090. This rainfall deficit situation has already been observed by several authors in West Africa for RCPs 4.5 and 8.5 [44,45].

The future climate data (temperature and precipitation) analysis conformed to those of Sylla [28], which clearly indicates that anthropogenic climate change will substantially impact extreme precipitation and temperature events and cause shifts in the different moisture zones.

\subsection{Calibration and Validation of River Discharge Simulations}

The results at the end of the calibration and validation tests of the GR2M model are presented in Figure 6. The Nash values obtained were 0.94 and 0.79 for calibration and validation, respectively. 
The observed and calculated hydrographs showed stumps (flow degradation). The reproduction of the observed and calculated hydrographs shows the low Nash values obtained in validation.

Indeed, the low flows were poorly reproduced and the flood flows underestimated. In the calibration or validation phase, there was a slight delay (delay or advance) between the simulated hydrograph and the observed hydrograph. However, on the whole, the calculated monthly average water slices reproduced the seasonal variations satisfactorily on the calibration sample and validation.

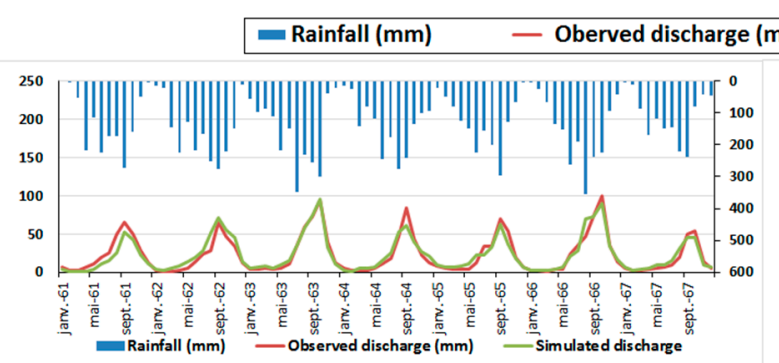

(a)

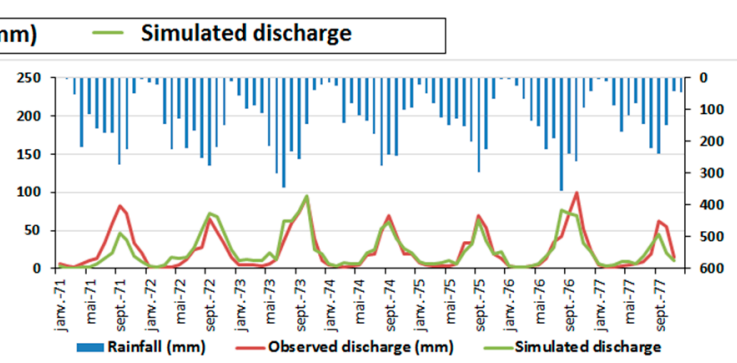

(b)

Figure 6. Hydrograms observed and simulated by the GR2M model at Soubré: (a) calibration; (b) validation.

\subsection{Impact of Climate Change on Natural River Discharge}

This section presents the impact of climate change on the watercourses run-off for 2040, 2060, 2080, and 2100 in the Sassandra watershed (Figure 7). Indeed, the flows simulated using the climatic parameters projected by RCP 4.5 and RCP 8.5 with the GR2M model showed a great variability with respect to the reference period.

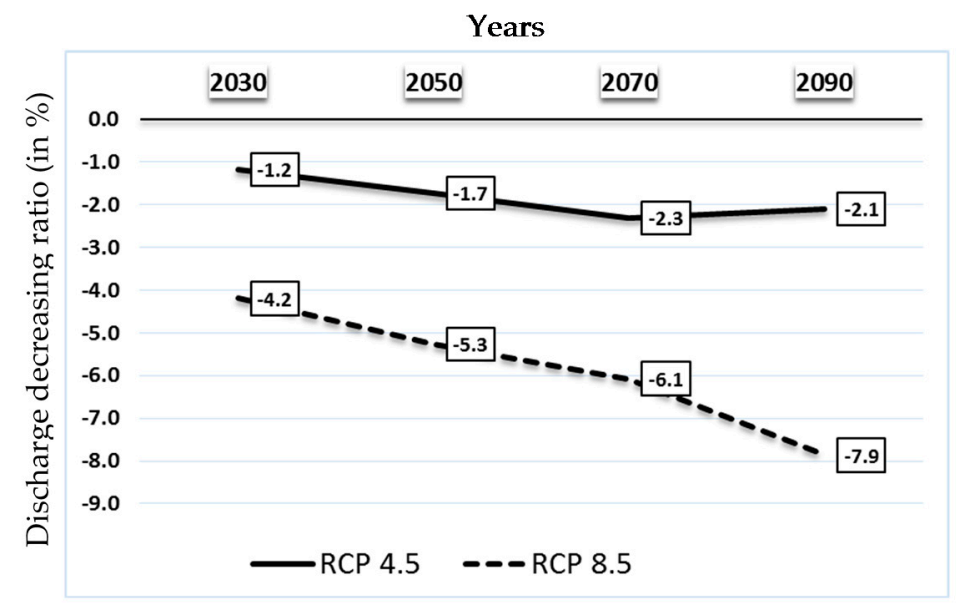

Figure 7. Future variations in the Sassandra natural river discharge when compared to the baseline per climate scenarios (RCPs 4.5 and 8.5).

Compared to the baseline (1961-1980), the discharge variation until 2100 was negative. For RCP 4.5 , the reduction rate went from $-1.2 \%$ for Horizon 2030 to a maximum decrease of $-2.1 \%$ in 2070 , followed by a slight rise to $-2.3 \%$ by 2090 . Discharges of RCP 8.5 decreased until it reached a rate of $-7.9 \%$ by 2090 . Thus, we could see that the simulated annual mean discharges varied (decreased) in the same way that the projected rainfall did with the RegCM4 model.

The decline of the observed discharge in this study corroborated the results found by the authors of [46], who conducted a study to assess the potential of climate change impacts on water inflows at the Manantali Dam (in the Senegal River watershed) by 2050. They used data from the CMIP5 
climate model under RCP 4.5 and RCP 8.5 and the hydrological model GR4J. However, Soro et al. [44] observed an increase in runoff for RCP 4.5 in the Bandama River Basin (Côte d'Ivoire).

\subsection{Impact of Climate Change on Headwater Inflows from Guinea}

Based on future rainfall on the Guinean part of the Sassandra River Basin, we evaluated the water quantity that flowed towards Côte d'Ivoire using Equation (5). Table 3 shows a reduction rate in the mean annual runoff and the total quantity of water transiting through the Guinean border for the Ivorian part of the Sassandra downstream. The results indicated that, for RCP 4.5, the variation will be $-48.3 \times 10^{6} \mathrm{~m}^{3} /$ year in 2030 to $-86.5 \times 10^{6} \mathrm{~m}^{3} /$ year in 2090 . The highest decrease would be observed in 2070 and will be $-95.2 \times 10^{6} \mathrm{~m}^{3}$ /year. RCP 8.5 , which had higher reductions compared with RCP 4.5, showed (in millions of $\mathrm{m}^{3}$ /year) 173.3, 217.6, 250.7, and 324.8 for Horizons 2030, 2050, 2070 and 2090, respectively.

Table 3. Runoff variation for the next decades of the 21st century.

\begin{tabular}{cccccc}
\hline \multicolumn{2}{c}{ Headwater Inflows from Guinea } & $\mathbf{2 0 3 0}$ & $\mathbf{2 0 5 0}$ & $\mathbf{2 0 7 0}$ & $\mathbf{2 0 9 0}$ \\
\hline \multirow{2}{*}{$\mathrm{RCP} 4.5$} & Runoff change (in \%) & -6.9 & -8.3 & -9.8 & -9.3 \\
& Volume change $\left(10^{6} \mathrm{~m}^{3} /\right.$ year $)$ & -48.3 & -71.6 & -95.2 & -86.5 \\
\hline \multirow{2}{*}{$\mathrm{RCP} 8.5$} & Runoff change (in \%) & -14.7 & -17.5 & -19.5 & -24.1 \\
& Volume change $\left(10^{6} \mathrm{~m}^{3} /\right.$ year $)$ & -173.3 & -217.6 & -250.7 & -324.8 \\
\hline
\end{tabular}

Even if this evaluation was roughly estimated, it provides an indication of the evolution of this parameter until 2090, which must be taken with some precaution given that the equation of Roudier et al. [41] (used for the assessment) was determined for the entire basin and not for a part of the basin. However, an assessment of water resources from Guinea, the West African water tower, with a distributed hydrological model could refine this assessment in the actual and future socio-economic development context in Guinea. The obtained discharges change using the equation of Roudier et al. [41], are almost similar to the values obtained by Bio [47] in Ouémé River Basin in Benin (West Africa). He observed discharges decreasing between $-15 \%$ to $-37 \%$ using the climate scenarios RCPs 4.5 and 8.5 rainfall data simulated by two regional climate models (DMI-HIRHAM5 and SMHI-RCA4). Otherwise, the works of Kouakou et al. [48] in the Comoé River Basin using the hydrological model, GR2M and the climate model, ICTP RegCM3 under A1 climate scenario data, revealed a decrease of discharges from $-18.8 \%$ to $-34 \%$ for the horizon $2031-2040$ and from $-40 \%$ to $-73 \%$ for $2091-2100$ horizon. The Comoé and Sassandra Rivers being in the same climate zone in West Africa, these significant variations can be explained by the projected climate data particularly the rainfall data (obtained from different models). Indeed, as mentioned by Rowell [49] and Orlowsky and Seneviratne [50] the models agree almost everywhere and for all seasons on the sign of changes of temperature indices and quantiles, but changes in rainfall (precipitation) are more uncertain.

\section{Conclusions}

This study proposed a methodology to assess the potential impacts of climate change on the natural discharge of the Sassandra trans-boundary watershed shared by Côte d'Ivoire and Guinea. Based on the future climate data projected to 2100 under scenarios RCP 4.5 and RCP 8.5 with the RegCM4 model, the situation for the coming decades of the 21st century was evaluated using the GR2M hydrological model. For both scenarios, we observed a reduction of the natural discharge for Horizons 2030, 2050, 2070, and 2090. This reduction was related to the decrease in rainfall associated with the increase in PET. The decrease was more important for RCP 8.5. However, the results also mainly depended on the global hydrological model used (GR2M), which was relatively simple and worked with two parameters. Thus, these results can be improved using a distributed hydrological 
model with a higher number of parameters. Furthermore, it is necessary to study the impact of climate change on the hydrology of West African trans-boundary Rivers for their integrated management.

Acknowledgments: The authors thank the Société d'Exploitation et de Développement Aéroportuaire, Aéronautique et Météorologique (SODEXAM) for historical climate data, the Office National d'Eau potable (ONEP) of Côte d'Ivoire for the river discharge data, and the United Nations University Institute for Natural Resources in Africa (UNU-INRA) in Accra (Ghana) for data acquisition.

Author Contributions: N.C. developed the ideas, prepared the data, and ran the model. N.C. and T.J.H.C. contributed to the analyses and interpretation of the results and wrote the paper. Z.M. and I.S. revised it.

Conflicts of Interest: The authors declare no conflict of interest.

\section{References}

1. Niasse, M. Climate-induced Water Conflict Risks in West Africa: Recognizing and Coping with Increasing Climate Impacts on Shared Watercourses. In Proceedings of the Human Security and Climate Change, Holmen Fjord Hotel, Oslo, Norway, 21-23 June 2005; pp. 1-15.

2. Frédéric, J. Maîtrise de l'eau et développement durable en Afrique de l'ouest: De la nécessité d'une coopération régionale autour des systèmes hydrologiques transfrontaliers. VertigO 2006, 7, 1-27.

3. Sidibé, S.; Oulaye, S. L'eau en Guinée. Rapport du Centre d'Observation, de Surveillance et d'Information Environnementales; COSIE: Conakry, Guinea, 2017; pp. 1-28. Available online: https:/ / unstats.un.org/unsd/environment/envpdf/UNSD_TogoWorkshop/Session\%207b_Guin\% C3\%A9e_L\%27Eau\%20en\%20Guin\%C3\%A9e.pdf (accessed on 27 September 2017).

4. Abdelkrim, B.S. Vulnérabilité et Adaptation Aux Changements Climatiques Dans les Oasis de la Région de Tafilalet-Maroc. Ph.D. Thesis, Université Cadi Ayyad, Marrakesh, Maroc, December 2013.

5. Mahé, G.; Olivry, J.C. Variations des précipitations et des écoulements en Afrique de l'ouest et centrale de 1951 à 1989. Sécheresse 1995, 6, 109-117.

6. Bricquet, J.P.; Bamba, F.; Mahé, G.; Touré, M.; Olivry, J.C. Evolution récente des ressources en eau de 1'Afrique atlantique. J. Water Sci. 1997, 3, 321-337. [CrossRef]

7. Servat, E.; Paturel, J.E.; Kouamé, B.; Travaglio, M.; Ouedraogo, M.; Boyer, J.F.; Lubès-Niel, H.; Fritsch, J.M.; Masson, J.M.; Marieu, B. Identification, caractérisation et conséquences d'une variabilité hydrologique en Afrique de l'Ouest et Centrale. IAHS J. 1998, 252, 323-337.

8. Savané, I.; Coulibaly, K.M.; Gioan, P. Etude comparative de trois méthodes de calcul du coefficient de tarissement des cours d'eau. Sécheresse 2003, 1, 37-42.

9. Ardoin, B.S. Variabilité Hydroclimatique et Impacts Sur Les Ressources en Eau de Grands Bassins Hydrographiques en Zone Soudano-Sahélienne. Ph.D. Thesis, Université de Montpellier II, Montpellier, France, April 2004.

10. Goula, B.T.A.; Konan, B.; Brou, Y.T.; Fadika, V.; Srohourou, B. Estimation des pluies exceptionnelles journalières en zone tropicale: Cas de la Côte d'Ivoire par comparaison des lois lognormale et de Gumbel. Hydrol. Sci. J. 2007, 52, 49-67. [CrossRef]

11. Kouakou, K.E.; Goula, B.T.A.; Savané, I. Impacts de la variabilité climatique sur les ressources en eau de surface en zone tropicale humide: Cas du bassin versant transfrontalier de la Comoé (Côte d'Ivoire-Burkina Faso). EJSR 2007, 16, 31-43.

12. Vissin, E.W. Impact de la Variabilité Climatique et de la Dynamique Des États de Surface Sur Les Écoulements du Bassin Béninois du Fleuve Niger. Ph.D. Thesis, Université de Bourgone, Dijon, France, December 2007.

13. Kouakou, K.E. Impacts de la Variabilité Climatique et du Changement Climatique Sur Les Ressources en eau en Afrique de l'Ouest: Cas du Bassin Versant de la Comoé. Ph.D. Thesis, Université Abobo-Adjamé, Abidjan, Côte d'Ivoire, February 2011.

14. Kouassi, A.M.; Kouamé, K.F.; Saley, M.B.; Biémi, J. Application du modèle de maillet à l'étude des impacts des changements climatiques sur les ressources en eau en Afrique de l'Ouest: Cas du bassin versant du N'Zi-Bandama (Cote d'Ivoire). IJSRM 2013, 3, 214-228.

15. Sakho, M. Incidences de L'instabilité des Ressources en eau de Surface sur les Performances Simulées d'un Système d'eau. Exemple du Sassandra en Côte d'Ivoire. Ph.D. Thesis, Université de Montpellier II, Montpellier, France, November 1991. 
16. Servat, E.; Sakho, M. Méthodologie simplifiée d'évaluation comparative des performances d'un système d'eau aménagé confronté à la sécheresse: Exemple de l'aménagement du Sassandra en Côte d'Ivoire. IAHS Publ. 1995, 231, 61-69.

17. Brou, Y.T.; Servat, E.; Paturel, J.E. Activités humaines et variabilité climatique: Cas du Sud forestier ivoirien. Int. Assoc. Hydrol. Sci. 1998, 252, 365-373.

18. Konan, B. Modélisation et Gestion Intégrée des Ressources en Eau Dans le Bassin Versant du Sassandra (Côte d'Ivoire). Ph.D. Thesis, Université d'Abobo-Adjamé, Abidjan, Côte d'Ivoire, April 2002.

19. Ardoin, B.S.; Dezetter, A.; Servat, E.; Mahe, G.; Paturel, J.E.; Dieulin, C.; Casenave, L. Évaluation des impacts $\mathrm{du}$ changement climatique sur les ressources en eau d'Afrique de l'Ouest et Centrale. Proceedings of symposium S6 held during the Seventh IAHS Scientific Assembly at Foz do Iguaçu, Brazil. IAHS Publ. 2005, 296, 194-202.

20. Rescan, M. Prévision des Ressources en eau en Afrique de L'ouest et Centrale Jusqu'en 2099 Par Application Des Sorties du Modèle D'évolution du Climat HadCM3 au Modèle Hydrologique GR2M; DEA; Université Montpellier II: Montpellier, France, 2005.

21. Goula, B.T.A.; Savane, I.; Konan, B.; Fadika, V.; Kouadio, G.B. Impact de la variabilité climatique sur les ressources hydriques des bassins de N'Zo et N'Zi en Côte d'Ivoire (Afrique tropicale humide). Vertigo 2006, 7. [CrossRef]

22. Yao, A.B. Evaluation Des Potentialités en Eau du Bassin Versant de la Lobo en Vue D'une Gestion Rationnelle (Centre-ouest de la Côte d'Ivoire). Ph.D. Thesis, Université Nangui Abrogoua, Abidjan, Côte d'Ivoire, January 2015.

23. Eldin, M. Le climat. In Le Milieu Naturel de la Cote d'Ivoire; Mémoires ORSTOM: Paris, France, 1971; pp. 77-108.

24. Guillaumet, J.L.; Adjanohoun, E. La végétation. In Le Milieu Naturel de la Côte d'Ivoire; Mémoires ORSTOM: Paris, France, 1971; pp. 161-232.

25. Noufou, C. Déforestation et Activités Agricoles en Côte d'Ivoire: Recherche d'un Nouvel Équilibre. Ph.D. Thesis, Faculté Des Études Supérieures de L'université Laval, Laval, QC, Canada, January 1998.

26. USAID (United States Agency for International Development). Guinea-Land Tenure and Property Rights Profile; USAID Country Profile; USAID: Washington, DC, USA, 2011; p. 23.

27. Perraud, A. Les sols. In Le Milieu Naturel de la Côte D'ivoire; Mémoires ORSTOM: Paris, France, 1971; pp. 265-391.

28. Sylla, M.B. Development and Analysis of Climatological Baseline and Climate Change Scenarios for Ecowas. Technical Report for United Nations University Institute for Natural Resources in Africa (UNU-INRA) Project: Climate Change, Agricultural Trade and Food Security in ECOWAS; United Nations University: Tokyo, Japan, 2015.

29. Giorgi, F.; Coppola, E.; Solmon, F.; Mariotti, L.; Sylla, M.B.; Bi, X.; Elguindi, N.; Diro, G.T.; Nair, V.; Giuliani, G.; et al. RegCM4: Model description and preliminary tests over multiple CORDEX domains. Clim. Res. 2012, 52, 7-29. [CrossRef]

30. Paeth, H.; Hall, N.M.J.; Gaertner, M.A.; Alonso, M.D.; Moumouni, S.; Polcher, J.; Ruti, P.M.; Fink, A.H.; Gosset, M.; Lebel, T.; et al. Progress in regional downscaling of West African precipitation. Atmos. Sci. Lett. 2011, 12, 75-82. [CrossRef]

31. Sylla, M.B.; Gaye, A.T.; Jenkins, G.S. On the fine-scale topography regulating changes in atmospheric hydrological cycle and extreme rainfall over West Africa in a Regional Climate Model projections. Int. J. Geophys. 2012, 1-15. [CrossRef]

32. Abiodun, B.J.; Lawal, K.A.; Salami, A.T.; Abatan, A.A. Potential influences of global warming on future climate and extreme events in Nigeria. Reg. Environ. Chang. 2013, 13, 477-491. [CrossRef]

33. Zaroug, M.A.H.; Sylla, M.B.; Giorgi, F.; Eltahir, E.A.B.; Aggarwal, P.K. A sensitivity study on the role of the Swamps of Southern Sudan in the summer climate of North Africa using a regional climate model. Theor. Appl. Climatol. 2013, 113, 63-81. [CrossRef]

34. Ibrahim, B.; Karambiri, H.; Polcher, J.; Yacouba, H.; Ribstein, P. Changes in rainfall regime over Burkina Faso under the climate change conditions simulated by 5 regional climate models. Clim. Dyn. 2014, 42, 1363-1381. [CrossRef]

35. Taylor, K.E.; Stouffer, R.J.; Meehl, G.A. An Overview of CMIP5 and the Experiment Design. Bull. Am. Meteorol. Soc. 2012, 93, 485-498. [CrossRef] 
36. Mora, D.E.; Campozano, L.; Cisneros, F.; Wyseure, G.; Willems, P. Climate changes of hydrometeorological and hydrological extremes in the Paute basin, Ecuodoreas Andes. Hydrol. Earth Syst. Sci. 2014, 18, 631-648. [CrossRef]

37. Mouelhi, S.; Michel, C.; Perrin, C.; Andréassian, V. Stepwise development of a two-parameter monthly water balance model. J. Hydrol. 2006, 318, 200-214. [CrossRef]

38. Kouakou, K.E.; Kouassi, A.M.; Kouadio, Z.A.; Goula Bi, T.A.; Savané, I. Modélisation hydrologique du bassin versant de la Comoé dans un contexte de changement climatique. IJIAS 2016, 15, 799-811.

39. Perrin, C. Vers Une Amélioration d'un Modèle Global Pluie-Début au Travers D'une Approche Comparative. Ph.D. Thesis, INPG, Grenoble, France/Cemagref, Antony, France, October 2000.

40. Nash, J.; Sutcliffe, J. River flow forecasting through conceptual models. Part I: A discussion of principle. J. Hydrol. 1970, 10, 282-290. [CrossRef]

41. Roudier, P.; Ducharne, A.; Feyen, L. Climate change impacts on runoff in West Africa: A review. Hydrol. Earth Syst. Sci. 2014, 18, 2789-2801. [CrossRef]

42. IPCC (Intergovernmental Panel on Climate Change). Climate Change 2013: The Physical Science Basis. In Contribution of Working Group I to the Fifth Assessment Report of the Intergovernmental Panel on Climate Change; Stocker, T.F., Qin, D., Plattner, G.-K., Tignor, M., Allen, S.K., Boschung, J., Nauels, A., Xia, Y., Bex, V., Midgley, P.M., Eds.; Cambridge University Press: Cambridge, UK, 2013. [CrossRef]

43. Sylla, M.B.; Nikiema, P.M.; Gibba, P.; Kebe, I.; Klutse, N.A.B. Climate Change over West Africa: Recent Trends and Future Projections. In Adaptation to Climate Change and Variability in Rural West Africa; Yaro, A.J., Hesselberg, J., Eds.; Springer International Publishing: Cham, Switzerland, 2016; pp. 25-40.

44. Soro, G.E.; Yao, A.B.; Kouamé, Y.M.; Goula Bi, T.A. Climate Change and Its Impacts on Water Resources in the Bandama Basin, Côte d'Ivoire. Hydrology 2017, 4, 18. [CrossRef]

45. Mbaye, M.L.; Hagemann, S.; Haensler, A.; Stacke, T.; Gaye, A.T.; Afouda, A. Assessment of Climate Change Impact on Water Resources in the Upper Senegal Basin (West Africa). Am. J. Clim. Chang. 2015, 4, 77-93. [CrossRef]

46. Bodian, A.; Dezetter, A.; Diop, L. Evolution des apports en eau au barrage de Manantali à l'horizon 2050. Int. J. Water Resour. Dev. 2015, 32, 1-13.

47. Biao, E.I. Assessing the Impacts of Climate Change on River Discharge Dynamics in Oueme River Basin (Benin, West Africa). Hydrology 2017, 4, 47. [CrossRef]

48. Kouakou, K.E.; Goula, B.T.A.; Kouassi, A.M. Analyze of climate variability and change impacts on hydro-climate parameters: Case study of Côte d'Ivoire. Int. J. Sci. Eng. Res. 2012, 3, 1-8.

49. Rowell, D. Sources of uncertainty in future changes in local precipitation. Clim. Dyn. 2012, 39, $1929-1950$. [CrossRef]

50. Orlowsky, B.; Seneviratne, S. Global changes in extreme events: Regional and seasonal dimension. Clim. Chang. 2012, 110, 669-696. [CrossRef] 